\title{
PORCINE MALIGNANT HYPERTHERMIA: ROLE OF SKELETAL MUSCLE IN INCREASED OXYGEN CONSUMPTION
}

\author{
Gerald A. Gronert, James J.A. Heffron, James H. Milde, \\ and Richard A. Theye.
}

\section{INTRODUCTION}

IT HAS BEEN SUGGESTED that malignant hyperthermia $(\mathrm{MH})$ is primarily a disorder of skeletal muscle, ${ }^{1,2}$ a hypothesis supported by recent evidence of myopathic changes in susceptible man and pigs. ${ }^{3,4}$ The major source of heat production in $\mathrm{MH}$ was considered to be anaerobic metabolism, ${ }^{5}$ but more recent studies ${ }^{6}$ show that aerobic metabolism contributed most of the heat in the initial phase of $\mathrm{MH}$, and about 50 per cent of the heat in the terminal stages. Although this increase in oxygen consumption $\left(\mathrm{Vo}_{2}\right)$ was assumed to occur within skeletal muscle ${ }^{6}$ there is no direct experimental evidence for this premise.

We have previously measured hind limb and whole body oxygen consumption $\left(\dot{V}_{2}\right)$ during $\mathrm{MH}$ in swine but were unable to account for the increase in whole body $\dot{\mathrm{Vo}}_{2}$ by extrapolation of the hind limb increases to that of the total skeletal muscle mass. ${ }^{7-9}$ Our model for these previous studies was based on several vulnerable assumptions. We presumed that the Fick equation ${ }^{10}\left(\dot{\mathrm{Vo}}_{2}\right.$ equals the product of blood flow and arteriovenous oxygen difference) could be applied to the unsteady state present during $\mathrm{MH}$, that hind limb venous drainage was isolated and venous collection was complete, that the response of hind limb muscle was representative of total skeletal muscle, and that the ratio $(0.50)$ of total skeletal muscle to whole body weight established by others ${ }^{11}$ in $100 \mathrm{~kg}$ swine applied to our $25-50 \mathrm{~kg} \mathrm{MH}$ susceptible swine. The present study was designed to examine more completely the contributions of the total skeletal muscle mass and also of the splanchnic region to the increase in whole body $\dot{\mathrm{V}} \mathrm{o}_{2}$ in $\mathrm{MH}$.

\section{Materials ANd Methods}

A screening test involving a brief inhalation of halothane ${ }^{7}$ was used to select ten $25-50 \mathrm{~kg}$ genetically susceptible Poland China swine to study whole-body and muscle $\mathrm{VO}_{2}$ (six animals) and splanchnic $\dot{V}_{\mathrm{O}_{2}}$ (four animals). For the studies several days later, all animals were given atropine $(0.4 \mathrm{mg}$ ) and thiopentone ( 10 to $15 \mathrm{mg} / \mathrm{kg}$ ) intravenously and ventilated through a tracheal tube using 50 per cent

Gerald A. Gronert, M.D., Associate Professor of Anesthesiology, Mayo Medical School. James J.A. Heffron, Ph.D., Senior Postdoctoral Fellow, Department of Anesthesiology. Richard A. Theye, M.D., Professor of Anesthesiology, Mayo Medical School, Department of Anesthesiology, Mayo Clinic and Mayo Foundation, Rochester, Minnesota 55901.

Supported in part by Research Grant GM-21729 from NIH, PHS.

This work was presented in part at the October, 1976 meeting of the American Society of Anesthesiologists in San Francisco, California. 
$\mathrm{N}_{2} \mathrm{O}-\mathrm{O}_{2}$ and additional thiopentone as needed ( 15 to $30 \mathrm{mg} / \mathrm{kg}$ ) during preliminary preparations. Blood $\mathrm{P}_{\mathrm{O}_{2}}, \mathrm{P}_{\mathrm{CO}_{2}}$ and $\mathrm{pH}$ were determined with electrodes at $37^{\circ} \mathrm{C}$; these were not corrected to actual body temperature. ${ }^{12}$ Oxygen content was determined from measurements of $\mathrm{P}_{\mathrm{O}_{2}}$ and oxyhaemoglobin concentration. ${ }^{13}$ Core temperature was measured by a right atrial thermistor.

To study whole body and muscle $\dot{V}_{0}$, catheters were placed in the carotid (a) and pulmonary $(\bar{v})$ arteries for samples and injection to determine cardiac output $(\dot{Q})$ by dye dilution and blood oxygen content $\left(\mathrm{C}_{0_{2}}\right)$. Whole body oxygen consumption $\left(\dot{V}_{\mathrm{O}_{2 \mathrm{~B}}}\right)$ was calculated as the product of $\dot{\mathrm{Q}}$ and $\left(\mathrm{Ca}_{\mathrm{O}_{2}}-\mathrm{C}_{\mathrm{V}_{2}}\right)$. For muscle $\dot{V O}_{2}$, caudal body blood flow was estimated by duplicate timed collection of blood flowing from the cannulated inferior vena cava (IVC), which was ligated just caudal to the renal veins. The venous reservoir was at the level of the IVC so that IVC flow was neither siphoned nor impeded. Collected blood was returned to the external jugular vein through a heat exchanger maintained at control body temperature. Collateral venous return was minimized by ligation of the inferior mesenteric vein near its junction with the superior haemorrhoidal vein and by toumiquets placed around abdominal, flank and back muscles at the level of the IVC ligature. The remaining vertebral venous system with connections through the lumbar veins to the azygous vein was demonstrated in this preparation to have minimal collateral flow, at the venous pressure present during these studies. Caudal body oxygen consumption ( $\dot{V}_{2 \mathrm{C}}$ ) was calculated as the product of IVC flow and $\mathrm{Ca}_{\mathrm{O}_{2}}-\mathrm{Crvc}_{\mathrm{O}_{2}}$ ) and expressed as $\mathrm{ml} \mathrm{O} / \mathrm{min} / \mathrm{kg}$ of caudal muscle weight, as determined at autopsy in every animal.

Total skeletal muscle oxygen consumption $\left(\dot{\mathrm{V}}_{\mathrm{O}_{2 M}}\right.$ ) was calculated as the product of $\dot{V}_{O_{2}}$ and the total skeletal muscle mass, and expressed relative to body weight. Total skeletal muscle mass was calculated from body weight and the ratios of skeletal muscle mass to body weight. While we previously used 0.50 for this ratio, based upon data from well-muscled $100 \mathrm{~kg}$ swine, ${ }^{11}$ other data ${ }^{14}$ suggested that this ratio might be 0.40 . Determination of dissectable carcass skeletal muscle in three animals of this group produced values of $0.39,0.39$ and 0.43 ; we used 0.40 in calculations.

To study splanchnic $\dot{V}_{2}$, splanchnic blood flow was estimated by duplicate timed collection of hepatic venous flow, which was isolated by ligation of the IVC above and below the liver. The collected flow and distal IVC flow were returned to the external jugular vein. Splanchnic $\dot{\mathrm{V}}_{2}$ was calculated as the product of hepatic flow and the difference between arterial and hepatic venous oxygen contents.

For both studies, ventilation was adjusted to provide a $\mathrm{Pa}_{\mathrm{CO}_{2}}$ of $40 \pm 2$ torr and was not changed thereafter. Control values were established from three sets of determinations obtained during a 15 -minute period. Continuous administration of halothane ( 1 per cent inspired in 50 per cent $\mathrm{N}_{2} \mathrm{O}-\mathrm{O}_{2}$ ) was begun and, 15 minutes later, SCh $(3 \mathrm{mg} / \mathrm{kg})$ was given intravenously. There were no therapeutic interventions. Measurements were repeated 10,20,25,30 and 40 minutes after starting halothane. Results are expressed as means \pm standard errors. Comparisons are by Student's t test for paired data, $\mathrm{P}<0.05$ considered significant. 


\section{$\dot{V}_{\mathrm{O}_{2}}$ IN PORCINE MALIGNANT HYPERTHERMIA}

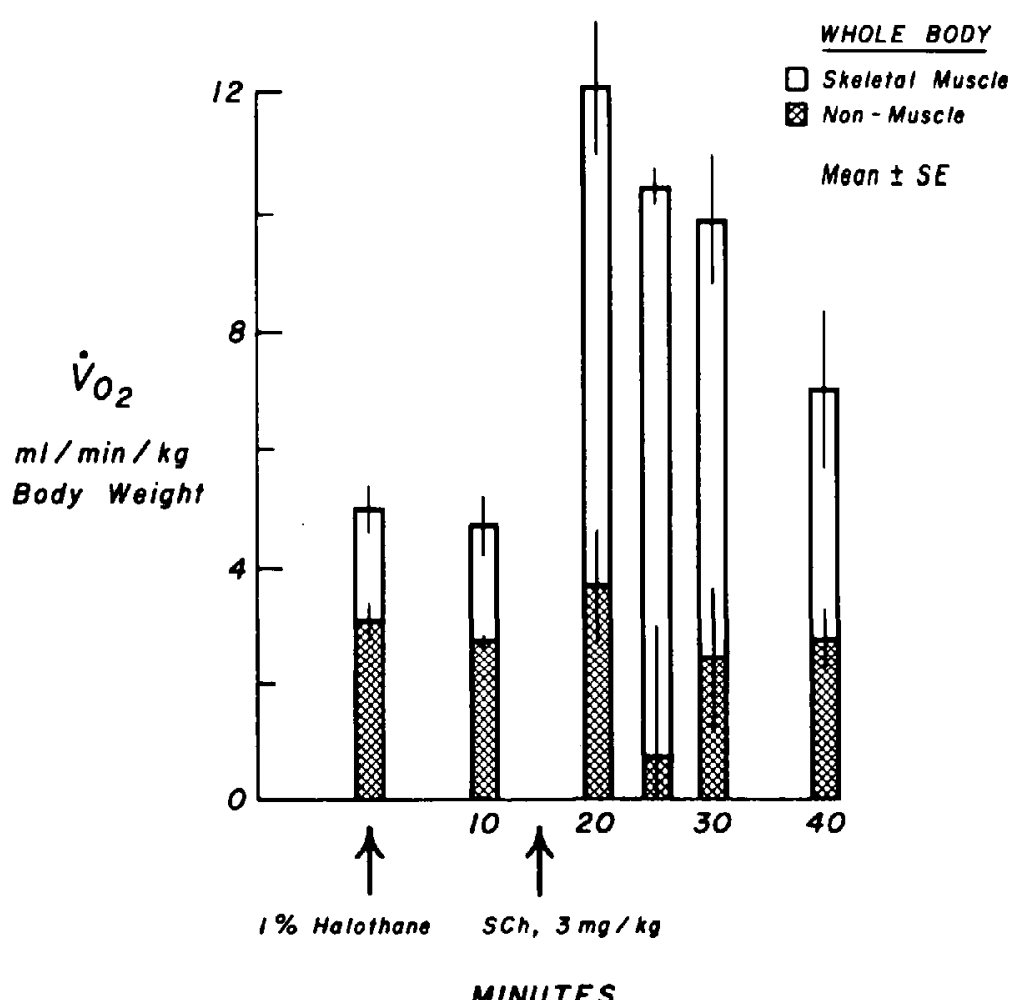

FicURE: Whole body (mean $\pm S E$ ), total skeletal muscle (mean) and non-muscle (mean \pm $\mathrm{SE}$ ) oxygen consumption during porcine $\mathrm{MH}$.

\section{Results}

$\dot{V}_{\mathrm{O}_{\mathrm{B}}}$ and $\dot{\mathrm{V}}_{\mathrm{O} \mathrm{M}}$ were unchanged ten minutes after introducing halothane (Figure). However, after 20, 25 and 30 minutes, both more than doubled with the combined triggers of halothane and SCh. The period from 20 to 30 minutes was the most stable phase of $\mathrm{MH}$ in these studies and the three measurements of $\dot{\mathrm{V}}_{\mathrm{O}_{2} \mathrm{~B}}$ and $\dot{V}_{O_{M}}$ have been averaged to provide an estimate of the contribution of increased muscle $\dot{V} \mathrm{O}_{2}$ to increased whole body $\dot{V} \mathrm{O}_{2}$ (Table). The mean increase in whole body $\dot{V}_{\mathrm{O}_{2}}$ of $6.08 \mathrm{ml} / \mathrm{min} / \mathrm{kg}$ of body weight was not significantly different from the mean estimated skeletal muscle contribution of $6.42 \mathrm{ml} / \mathrm{min} / \mathrm{kg}$ of body weight. Values at 40 minutes were not included because of declining perfusion, although increases in $\dot{V}_{\mathrm{o}_{2 \mathrm{~B}}}$ and $\dot{V} \mathrm{O}_{2 \mathrm{M}}$ were still approximately equal (Figure). During the period from 20 to 30 minutes, $\dot{Q}$ tended to increase, caudal blood flow doubled, and arterial pressure decreased to the normal range (Table).

The trend of splanchnic $\dot{\mathrm{V}}_{2}$ during $\mathrm{MH}$ was to decrease, as mean control $\dot{\mathrm{Vo}}_{2}$ was $2.19 \pm 0.18 \mathrm{ml} / \mathrm{min} / \mathrm{kg}$ body weight and the average 20 - to 30 -minute value, 
CANADIAN ANAESTHETISTS' SOCIETY JOURNAL

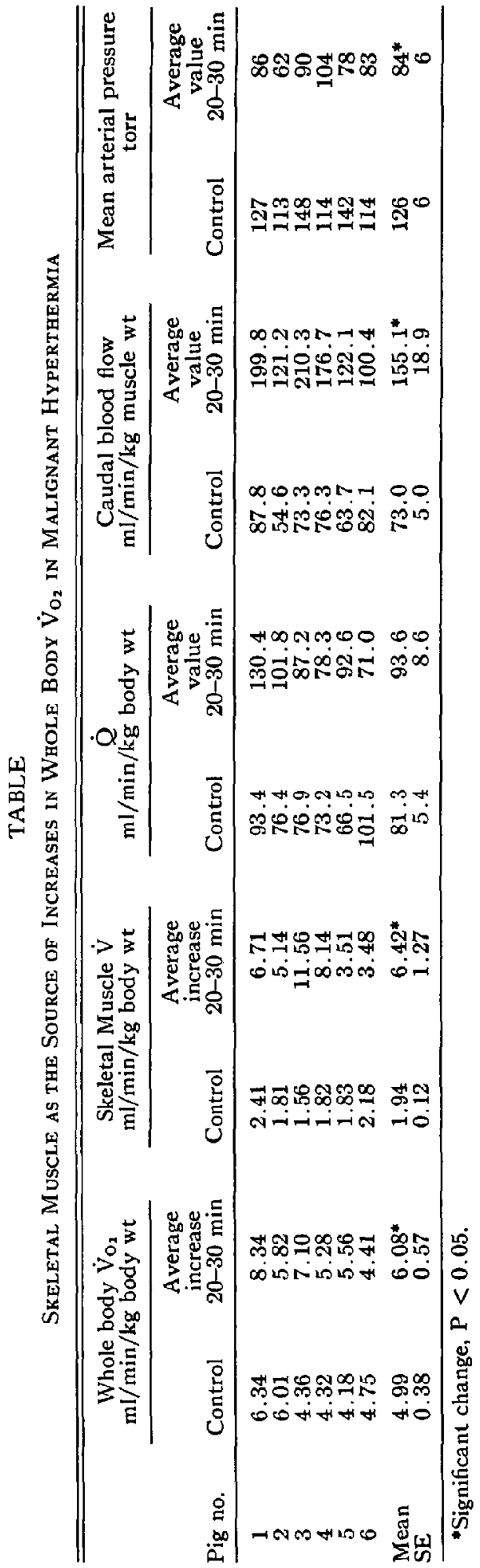


not significantly different, was $1.61 \pm 0.36$. In addition, splanchnic arterial lactate levels exceeded splanchnic venous, i.e., the liver and gut were not producing lactate. $\mathrm{Pa}_{\mathrm{O}_{2}}$ was $>100$ torr in all animals. The mean increase in core temperature at 30 minutes was limited to $1.6^{\circ} \mathrm{C}$, probably because caudal blood was maintained at control body temperature. Measured caudal muscle mass equalled body weight $\times 0.155 \pm 0.0013$. All swine followed the expected course ${ }^{9}$ of $\mathrm{MH}$ in regard to blood lactate, $\mathrm{P}_{\mathrm{CO}_{2}}, \mathrm{pH}$, catecholamines, and $\mathrm{K}+$ (not reported).

\section{Discussion}

The hyperthermia observed in this study was not severe because a heat exchanger was used during reinfusion of venous blood from the IVC. However, the rise in temperature in $\mathrm{MH}$ is secondary to the marked changes in metabolism. ${ }^{7-9}$ Since we observed the usual degree of acidosis, hyperkalaemia, and increases in plasma catecholamines and whole body $\ddot{\mathrm{V}}_{2}$, the technique apparently did not alter the course of $\mathrm{MH}$.

The present data support the hypothesis that skeletal muscle is collectively

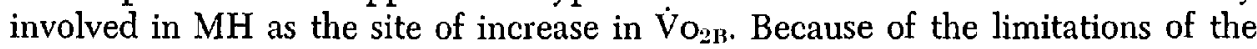
Fick equation, ${ }^{10}$ the averaged comparisons were made during the period of maximum increase in $\dot{V}_{2}$ and during which perfusion was well maintained. An apparent redistribution of flow contributed to the unsteady metabolic state at 20 to 30 minutes. Caudal blood flow doubled while $\dot{Q}$ did not increase significantly. There were therefore considerable variations in data from individual animals (Table). Comparisons were not feasible as $\mathrm{MH}$ progressed further because $\dot{\mathrm{V}}_{2}$ decreased due to the onset of circulatory failure and inadequate delivery of oxygen to tissues.

Although the metabolism of individual muscles may respond differently in $\mathrm{MH}$, it is technically difficult to isolate an intact muscle preparation. Our caudal preparation yields data from about 39 per cent of the total skeletal muscle mass, thus providing information that would approximate the average response of skeletal muscle. Earlier studies underestimated by 40 per cent the contribution of muscle to changes in $\dot{\mathrm{VO}}_{2}$ during $\mathrm{MH}^{7-9}$ This discrepancy was probably due to a large unmeasured collateral blood flow was well as to a projection based upon measurements in a smaller mass of muscle which was perhaps less representative of average muscle. Overestimation of total skeletal muscle mass in these earlier studies (see Materials and Methods) would result in over-estimation rather than underestimation of the contribution of skeletal muscle, but the error was insufficient to balance the calculations. ${ }^{7-9}$

Considering the $\dot{\mathrm{VO}}_{2}$ of tissues other than skeletal muscle, myocardial $\dot{\mathrm{Vo}}_{2}\left(\dot{\mathrm{VO}}_{2 \mathrm{H}}\right)$ would be expected to increase during $\mathrm{MH}$ due to the effects of fever and tachycardia. In general, $\dot{V}_{2 \mathrm{H}}$ is affected by several factors, most importantly temperature, arterial pressure, heart rate, and stroke volume. ${ }^{15}$ Previous studies have demonstrated that early in $\mathrm{MH}$ triggered by halothane ${ }^{7}$ or by halothane and succinylcholine ${ }^{9}$ there is an increase in pulse rate, essentially no change in $\dot{Q}$ and a decrease in pressure, all of which the present studies confirm. The net effect, calculted from values for $\dot{Q}$ and mean arterial pressure, ${ }^{15}$ is a decrease in $\dot{V} \mathrm{O}_{2 \mathrm{H}}$ secondary to decreased left ventricular external work. This would not be offset by the 
increase in temperature observed in these studies. The liver is responsible for about 70 per cent of splanchnic metabolism ${ }^{16}$ and the present data suggest that it does not actively participate in $\mathrm{MH}$.

The increase in $\hat{\mathrm{O}}_{2}$ during $\mathrm{MH}$ is small in comparison to potential maximal increases $^{17}$ and accounts for no more than 50 per cent of the heat produced during $\mathrm{MH}$, as calculated from our data ${ }^{7}$ and others. ${ }^{5}$ Remaining sources of heat ${ }^{5}$ include glycolysis, hydrolysis of high energy phosphates involved in ion transport and contraction-relaxation, and neutralization of hydrogen ion. Assuming that $\mathrm{MH}$ primarily involves a sustained increase in the intracellular concentration of calcium, then considerable and continuous amounts of energy are needed to transport this calcium into the sarcoplasmic reticulum and perhaps the mitochondria. ${ }^{4}$ The immediate source of this energy is creatine phosphate and adenosine triphosphate, which are rapidly consumed. Although regeneration of these compounds would be vastly more efficient by aerobic rather than by glycolytic processes, the latter is apparently the primary source, since the observed increase in $\dot{V O}_{2}$ during $\mathrm{MH}$ is small.

\section{SUMMARY}

During malignant hyperthermia $(\mathrm{MH})$ induced by halothane and succinylcholine, oxygen consumption $\left(\dot{V}_{\mathrm{O}_{2}}\right)$ of whole body, muscle and the splanchnic area was calculated from measurements of blood flow and arteriovenous oxygen content difference. Caudal body blood flow was isolated and measured (six animals) for determination of average muscle $\dot{V}_{2}$ in the hind limbs, buttocks, and flanks. The increase in muscle $\dot{V}_{2}$ was extrapolated to total skeletal muscle and compared with the increase in whole body $\mathrm{VO}_{2}$ (same six animals). The average increase in $\dot{V}_{2}$ for both total muscle and whole body during the period of maximum increase was about $6 \mathrm{ml} \mathrm{O}_{2} / \mathrm{min} / \mathrm{kg}$ body weight. Splanchnic $\dot{V O}_{2}$ (four animals) tended to decrease during $\mathrm{MH}$. The data support the hypothesis that the metabolic changes in $\mathrm{MH}$ are due to a disorder of skeletal muscle and that the increase in whole body $\dot{\mathrm{V}}_{2}$ is due to the increase in muscle $\dot{\mathrm{VO}}_{2}$.

\section{RÉSUMÉ}

Le but de cette étude effectuée chez le porc était de déterminer la consommation d'oxygène totale ainsi que celle des muscles squelettiques et celle du territoire splanchnique au cours d'épisodes d'hyperthermie maligne induits avec Halothane et Succinlycholine. Cette consommation a pu être évaluée au moyen de prises de débits et de mesures des différences artério-veineuses en oxygène.

En isolant la circulation des membres inférieurs, on a pu mesurer le débit de cette région et établir la consommation d'oxygène de la masse musculaire isolée. Par extrapolation, on a pu ensuite faire la détermination de la consommation d'oxygène de la masse musculaire totale.

On a trouvé que la consommation d'oxygène totale et celle de la masse musculaire étaient augmentées d'environ $6 \mathrm{ml} / \mathrm{kg} / \mathrm{min}$.; celle du lit splanchnique (quatre animaux) avait tendance à diminuer.

Ces résultats supportent l'hypothèse que les changements métaboliques observés 
dans l'hyperthermie maligne reflètent un trouble du muscle squelettique et que l'augmentation de la consommation d'oxygène de l'organisme est due à une augmentation de consommation au niveau des muscles squelettiques.

\section{TABLE OF SYMBOLS}

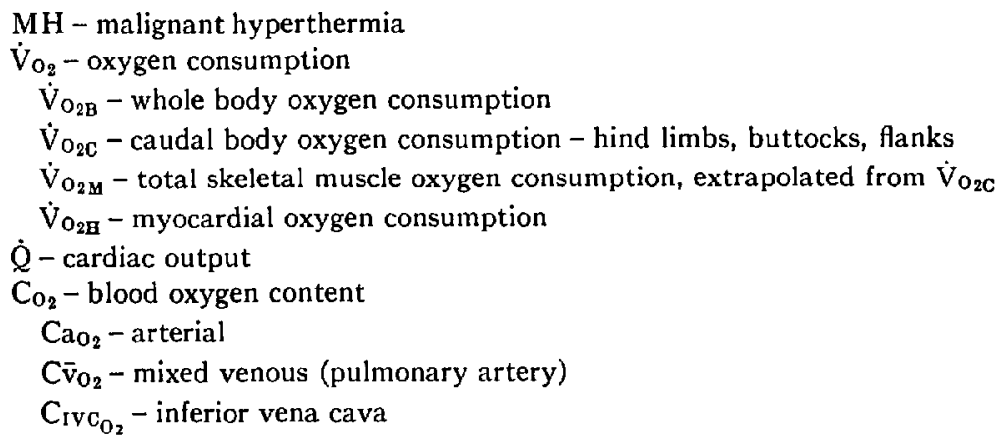

\section{REFERENCES}

1. IsaAcs, H. \& Barlow, M.B. Malignant hyperpyrexia during anaesthesia: possible association with subclinical myopathy. Brit. Med. J. 1: 275 (1970).

2. Britt, B.A., Kalow, W., Gordon, A., Humphrey, J.G., \& Rewcastle, N.B. Malignant hyperthermia: an investigation of five patients. Canad. Anaesth. Soc. J. 20: 431 (1973).

3. Gullotta, F. \& Helpap, B. Histologische, histochemische und elektronenmikroskopische Befunde bei maligner Hyperthermie. Virchows. [Path. Anat.] 367: 181 (1975).

4. Campion, D.R. \& Toped, D.G. A review of the role of swine skeletal muscle in malignant hyperthermia. J. Anim. Sci. 41: 779 (1975).

5. Berman, M.C., Harrison, G.G., Bull, A.B., \& Kench, J.E. Changes underlying halothane-induced malignant hyperpyrexia in Landrace pigs. Nature 225: 653 (1970)

6. Hall, G.M., Bendall, J.R., Lucke, J.N., \& Lister, D. Porcine malignant hyperthermia. II: Heat production. Brit. J. Anaesth. 48: 305 (1976).

7. Gronert, G.A. \& Theye, R.A. Halothane-induced porcine malignant hyperthermia: metabolic and hemodynamic changes. Anesthesiology 44: 36 (1976).

8. Gronert, G.A., \& Theye, R.A. Suxamethonium-induced porcine malignant hyperthermia. Brit. J. Anaesth. 48:513 (1976).

9. Gronert, G.A., Milde, J.H., \& Theye, R.A. Porcine malignant hyperthermia induced by halothane and succinylcholine: failure of treatment with procaine or procainamide. Anesthesiology 44: 124 (1976).

10. ZierLer, K.L. Theory of the use of arteriovenous concentration differences for measuring metabolism in steady and non-steady states. J. Clin. Invest. 40: 2111 (1961).

11. Allen, C.E., Thompson, E., \& Hegarty, V. Physiological maturity of muscle and adipose cells in meat animals. Proceedings of American Meat Science Assoc., pp. 8-27 (1974)

12. RAHN, H. Body temperature and acid-base regulation (Review article). Pneumonologie 151: 87 (1974)

13. Theye, R.A. The determination of $\mathrm{O}_{2}$ and $\mathrm{CO}_{2}$ content in blood containing halothane. Anesthesiology 30:325 (1969).

14. Martin, T.G., Stant, E.G., Jr., Kessler, W.V., Jumge, M.D., \& Christian, J.E. Associations of body potassium, chemical composition, and carcass measurements with fat-lean composition determined by physical separation, Body Composition in Animals and Man, 13th ed., p. 428, Washington, D.C., National Academy of Sciences (1968).

15. Theye, R.A. The contributions of individual organ systems to the decrease in whole-body $\dot{V}_{\mathrm{O}_{2}}$ with halothane. Anesthesiology 37: 367 (1972).

16. Theye, R.A., Kuster, G., \& Dawson, B. Effect of halothane on splanchnic hemodynamics and oxygen consumption. Current Res., Anesth. Analg. 51: 59 (1972).

17. Roninson, S. Physiology of muscular exercise, Medical Physiology. Edited by V.B. Mountcastle, p. 1273, St. Louis, C.V. Mosby (1974). 